\title{
Papo de engraxate
}

\author{
Sônia Queiroz
}

\section{SciELO Books / SciELO Livros / SciELO Libros}

QUEIROZ, S. Papo de engraxate. In: Pé preto no barro branco: a língua dos negros da Tabatinga [online]. 2nd ed. rev. Belo Horizonte: Editora UFMG, 2018, pp. 15-16. ISBN: 978-85-423-0305-6. https://doi.org/10.7476/9788542303056.0003.

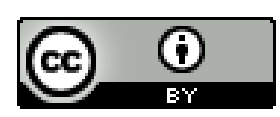

All the contents of this work, except where otherwise noted, is licensed under a Creative Commons Attribution 4.0 International license.

Todo o conteúdo deste trabalho, exceto quando houver ressalva, é publicado sob a licença Creative Commons Atribição 4.0.

Todo el contenido de esta obra, excepto donde se indique lo contrario, está bajo licencia de la licencia Creative Commons Reconocimento 4.0. 


\section{PAPO DE ENGRAXATE}

Meu primeiro contato com a Língua do Negro da Costa se deu ainda na minha infância. Eu vivia em Bom Despacho, onde, como em toda pequena cidade do interior de Minas, tudo gira em torno da igreja matriz. À volta da igreja, os casais passeiam, os políticos conchavam, as crianças brincam, passam os enterros e as procissões, as comadres (e os compadres) comentam. Enfim, tudo acontece e de tudo se toma conhecimento na praça da matriz.

Nessa praça, em Bom Despacho, em frente à porta principal da igreja, havia sempre alguns engraxates que, enquanto lustravam sapatos, conversavam numa língua ininteligível para os não-iniciados e que diziam de origem africana. Eram meninos pobres vindos da Tabatinga ou da Cruz do Monte - ruas da periferia da cidade cujos habitantes sempre foram tidos por marginais. De tanto passar por ali, a gente do centro da cidade acabava por aprender alguma coisa. Viriango 'soldado' e ingura 'dinheiro', significativamente, são as duas palavras que me ficaram na memória, daquela época.

Lembro-me ainda de uma curiosidade relacionada com o caráter de código secreto atribuído à língua por seus falantes. O tio de um amigo meu, passando férias na cidade, interessou-se pela língua dos engraxates e lhes propôs a compra do seu "dicionário". A meninada se reuniu, discutiu o assunto e resolveu que não havia negócio a fazer com o homem. Que se fosse ele com o seu dinheiro. Eles ficariam lá com a língua deles.

Hoje, os engraxates não existem mais à porta da igreja, e parece que a Língua do Negro da Costa, como é chamada por muitos de seus falantes, também tende a desaparecer. Deixá-la morrer sem um registro seria desconhecer ou pelo menos subestimar a importância que tem o estudo de falares como esse para um melhor conhecimento da nossa realidade lingüística e sócio-cultural. Compreendi isso sobretudo a partir das reflexões a que me levaram as leituras feitas em Sociolingüistica, durante meu curso de pós-graduação em Letras. 
Acabei por escolher a Língua do Negro da Costa como tema da minha dissertação de Mestrado, transformando-a, assim, de objeto de memória em objeto de pesquisa.

Sônia Queiroz 